\title{
The Effect of Air Pollution on Fertility Intentions
}

\section{Wpływ zanieczyszczenia powietrza na płodność}

\author{
Yunrong Li
}

\author{
School of Economics and Management, Dali University. Hongsheng Road 2, \\ Dali Ancient City, 671003, Yunnan, China \\ Email: liyunrong@swufe.edu.cn,ORCID:0000-0002-3491-3401
}

\begin{abstract}
Together with fast economic growths in recent decades and subsequent environmental pollutions, fertility rates have declined dramatically in China. Considering fertility intention is an essential predictor for fertility rate, we examine the effect of air pollution on fertility intentions in China. Using data from the China General Social Survey (CGSS) collected in 2010 and 2013, we find a negative and significant impact of air pollution on people's fertility intentions. More importantly, after we restrict the sample to people who have been living in current places for a long period of time, the estimated effect of air pollution decreases but remains significant, indicating existence of endogeneity of air pollution on fertility intentions. For the government to take measures to raise fertility rates in China, it is important to take into account the factor of air pollution.
\end{abstract}

Key words: air pollution, fertility intentions

\section{Streszczenie}

Wraz z szybkim wzrostem gospodarczym w ostatnich dziesięcioleciach i późniejszym zanieczyszczeniem środowiska, wskaźniki dzietności w Chinach dramatycznie spadły. Biorąc pod uwagę, że intencja płodności jest podstawowym predyktorem współczynnika dzietności, badamy wpływ zanieczyszczenia powietrza na intencje dzietności w Chinach. Korzystając z danych z China General Social Survey (CGSS), zebranych w 2010 i 2013 r., wskazujemy na negatywny i znaczący wpływ zanieczyszczenia powietrza na intencje ludzi w zakresie płodności. Co ważniejsze, po ograniczeniu próby do osób, które mieszkają w obecnych miejscach od dłuższego czasu, szacowany wpływ zanieczyszczenia powietrza maleje, ale pozostaje znaczący, wskazując na istnienie endogeniczności zanieczyszczenia powietrza na intencje płodności. Stwierdzamy, że aby rząd mógł podjąć działania mające na celu podniesienie współczynnika dzietności w Chinach, konieczne jest uwzględnienie czynnika zanieczyszczenia powietrza.

Słowa kluczowe: zanieczyszczenie powietrza, płodność

\section{Introduction}

Currently fertility rates have remained at low levels in many developed countries and have declined dramatically in China. According to the study of the World Bank, fertility rate has decreased from 5.6 in 1980 to 1.6 in 2017. Literature has investigated factors that may have affected fertility rates, including economic, familial, and environmental factors. Recent studies examined the relationship between local air pollution and human fertility rates and found significantly decreased fertility rates by increases in air pollution levels (Nieuwenhuijsen et al., 2014; Xue and Zhang, 2018).

Fertility intention is one of the essential predictors of subsequent fertility behavior (Schoen et al., 1999). Arnocky et al. (2012) define individual fertility intention as the desire to have versus not to have children or the desire for a specific number of children across the lifespan. Understanding the determinants of fertility intentions can help us understand the determinants of fertility rates. Very few papers have studied the relation between air pollution and fertility intentions. Guo et al. (2019) looked into the effect 
of air pollution on the second birth intentions of the floating population in China and suggested a negative impact.

As noted by Guo et al. (2019), air pollution can reduce fertility intention in at least two ways: Firstly, research has shown that exposure to air pollution during pregnancy harms physical and mental development of the fetus or the newborn, and this effect can last until the childhood phase. For the sake of the health of newborn babies, women at childbearing ages usually reduce or postpone their fertility intentions. For instance, studies suggest that exposure to air pollution significantly affects fetal growth, miscarriage, live birth rates, preterm birth, and birth weight (Maisonet et al., 2004; Stieb et al., 2012; Dadvand et al., 2013; Frutos et al., 2015; Rich et al., 2015). Perera et al. (2012) find that children growing up in areas with heavy pollution are more likely to have distractions, anxiety disorders, and depression than their counterparts growing up in areas with little pollution.

Secondly, air pollution affects the physical and mental health of child-bearing women. Existing literature shows a causal link between morbidity or mortality and ambient particulate matter (PM) in air pollution (Zhou et al., 2015; Wong et al., 2015). Smog also affects the mental health of people, increasing anxiety, depression, and suicidal events (Chattopadhyay et al., 1995; Kim et al., 2015; Buoli et al., 2018).

Ghimire and Mohai (2005) examined the relationship between local environmental concerns and contraceptive use in Nepal. They found that concern over local crop production was positively associated with contraceptive use. Similar to what Guo et al. (2019) propose, Ghimire and Mohai (2005) reason that those who believe that environment quality poses a considerable threat to the self or offspring might be less likely to reproduce.

The objective of this paper is to estimate the effect of air pollution on people's fertility intentions in China. To obtain causal relation between air pollution and fertility intentions, it is essential to address the endogeneity issue. Potential endogeneity may arise from that people choose places to live according to their fertility intentions, i.e., people with higher fertility intentions choose to live in places with less air pollution. Thus, the effect of air pollution on fertility intention found in Guo et al. (2019) may be overestimated by focusing on the floating population. The paper contributes to the current literature in two aspects. First, we use a nationally representative sample of China. Second, we address the potential endogeneity of air pollution by restricting the estimation sample to people who have been living in current places for a long period of time.

We find a significant negative impact of air pollution on people's fertility intentions. More importantly, when estimation sample is restricted to people who have been living in current locations for at least five years, the magnitude of the effect of air pollution declines but remains significant.

The rest of the paper is organized as follows. Section 2 describes the data, defines variables, and presents descriptive statistics of the variables. Section 3 presents the econometric model and estimation results. Section 4 concludes.

\section{Data}

\subsection{The CGSS surveys}

The data we use in the paper come from the China General Social Survey (CGSS). Since 2013, GCSS has continuously conducted cross-sectional surveys of more than 10,000 families in mainland China, covering almost all province-level administrative units. CGSS has collected data at various levels, i.e., community, family and individuals. The surveys include information about income, education, lifestyle, social attitude, social security, etc. For data availability of this study, we use the data from 2010 and 2013 surveys. ${ }^{1}$ We refer to these two surveys as CGSS2010 and CGSS2013 hereafter.

Respondents of the CGSS are aged above 16 years old. There are originally 11,783 and 11,438 respondents from CGSS2010 and CGSS2013. We look at both rural and urban residents. Since we intend to study the determinants of fertility intentions, we restrict the estimation sample to respondents who are aged between 17 and 45 . After dropping observations with missing values in important variables, we have 4,948 respondents left in the final estimation sample. The sample will be referred to as the benchmark sample hereafter.

\subsection{Variable definitions}

The outcome variable of interest of the paper is fertility intention. Based on the answer to the question of CGSS2010 and CGSS2013, If there were no policy restrictions, how many children would you like to have, we define the fertility intention as a continuous variable.

The independent variable of interest is the severity of local air pollution. In CGSS2010 and CGSS2013, the respondent was asked the question, How severe is the air pollution in the place where you live. The answer defines the value of the severity variable which ranges from 1 to 4 indicating lowest to highest level of severity.

Since we use subjective evaluation of local air pollution as our independent variable, potential endogeneity may exist. For instance, people who desire more children are more sensitive to air pollution and are more likely to rate the air pollution as serious. If air pollution negatively affects fertility intentions,

\footnotetext{
1 To download the data, see: http://www.cnsda.org/index.php?r=site/datarecommendation.
} 
Table 1. Descriptive Statistics

\begin{tabular}{|c|c|c|}
\hline \multicolumn{3}{|c|}{ Panel A: Dependent and key independent variables } \\
\hline Fertility & 1.79 & \\
\hline Air pollution & 2.31 & \\
\hline Correlation & $-0.053 * * *$ & \\
\hline \multicolumn{3}{|c|}{ Panel B: Sample means of variables by fertility intentions } \\
\hline & Low fertility intention & High fertility intention \\
\hline & $(1)$ & $(2)$ \\
\hline Air pollution & 2.40 & 2.27 \\
\hline Gender & 0.48 & 0.52 \\
\hline Age & 33.65 & 34.72 \\
\hline Minority & 0.08 & 0.10 \\
\hline Married & 0.74 & 0.83 \\
\hline Tertiary education & 0.30 & 0.24 \\
\hline Health & 4.14 & 4.07 \\
\hline Work status & 0.82 & 0.83 \\
\hline Hours of working per week & 40.55 & 42.69 \\
\hline Health insurance & 0.84 & 0.88 \\
\hline Social security & 0.57 & 0.56 \\
\hline Personal income (1000 yuan) & 20.21 & 19.56 \\
\hline Family income (1000 yuan) & 45.49 & 44.97 \\
\hline Number of obs. & 1,421 & 3,527 \\
\hline
\end{tabular}

Note: Figures in the table are computed from the benchmark sample which consists of respondents who are aged $17-45$.

this endogeneity can lead to underestimation of the effect of air pollution. We deal with this issue by measuring air pollution using sample means of the subjective evaluation of air pollution at the county level within each survey year. We expect the magnitude of the estimated effect of air pollution would increase after using the sample means if air pollution has an adverse effect on fertility intentions.

To avoid estimation biases, we control for individual characteristics that may affect both fertility intentions and subjective evaluations of air pollution. Specifically, we control for gender, age, educational attainment, ethnicity, marital status, self-reported health condition, work status, hours of working per week, health insurance status, social security status, personal annual income, and family annual income. Provincial and year dummies are used to control for differences across provinces and years.

\subsection{Descriptive statistics}

Based on the benchmark sample, we report sample means of fertility intention and subjective evaluation of severity of local air pollution and the correlation between these two variables in panel A of Table 1. Panel B of Table 1 presents sample means of variables used in the paper by fertility intentions. Figures in column 1 are computed from respondents who would like to have one or no child under no policy restrictions, while those in column 2 are from respondents who would like to have more than one child under no policy restrictions.

As we can see in panel $\mathrm{A}$, the average number of children the respondent would like to have under no policy restrictions is 1.79 . Only $1.6 \%$ respondents would not want any child, $27.1 \%$ would like to have one child, and $71.3 \%$ would like to have more than one child. $61 \%$ respondents rate the air pollution in the places where they live as not severe at all or not so severe, while the rest rate local air pollution as quite severe or very severe. The correlation between the fertility intention and air pollution is -0.053 which is significant at $1 \%$ level.

As is shown in panel $\mathrm{B}$, the mean of the severity of air pollution is larger for those who have lower fertility intentions than those who have higher fertility intentions (2.40 Vs 2.27). Males, those who belong to minority groups and the married on average have higher fertility intentions. Those who have obtained tertiary education have lower fertility intentions. People who report better health conditions tend to have higher fertility intentions. Health insurance appears to be positively correlated with fertility intentions. Annual personal income and family income seem to be negatively associated with fertility intentions. 


\section{Econometric Analyses}

\subsection{The model}

The objective of the paper is to examine the effect of air pollution on people's fertility intentions. We estimate the following model.

$$
\begin{aligned}
& F_{i} \\
& =\alpha_{0}+\alpha_{1} A_{i r_{i}}+\beta^{\prime} X_{i} \\
& +\varepsilon_{i}
\end{aligned}
$$

where $i$ denotes the respondent. $F$ is the fertility intention of the respondent. Air is the severity of local air pollution where the respondent lives. We use two measures to present air pollution. One is reported by the respondent and is a subjective evaluation of severity of air pollution. The other is sample means of this subjective evaluation variable at the county level within each survey year. Vector $X$ includes individual characteristics of the respondent, namely gender, age, whether belongs to a minority group, whether is married, whether has obtained tertiary education, self-reported health condition, work status, hours of working per week, whether has health insurance and social security, annual personal income, and annual family income. Self-reported health condition ranges from 1 to 5 indicating lowest to highest level of health condition. Province and year dummies are also included in $X . \varepsilon$ is the error term.

We estimate equation (1) using an OLS estimator. Cluster-robust standard errors at the county level are estimated.

As mentioned before, there can be potential endogeneity arising from that respondents choose living locations according to their fertility intentions, i.e., people with higher fertility intentions choose to live in places with less pollution. To account for this issue, we further restrict the estimation sample to respondents who have been living in current places at the time of the interview for at least five years. This can presumably alleviate the bias in the estimates caused by the endogeneity.

\subsection{The effect of air pollution on people's fertility intentions}

Estimation results of equation (1) are reported in Table 2. Estimation results using the benchmark sample are in columns 1 and 2; results using the sample of respondents who have been living in current places for at least five years are in columns 3 and 4 . When air pollution is measured using subjective evaluations of the respondents, estimates are reported in columns 1 and 3; when air pollution is measured using sample means of the subjective evaluations at the county level within each survey year, estimates are given in columns 2 and 4. Standard errors are in parentheses.
As we can see in column 1, subjective evaluation of severity of air pollution has a negative impact on fertility intentions. If the severity increases by one level, the fertility intention will decrease by 0.024 children. The magnitude of the effect is not large but significant. When air pollution is measured using sample means of the subjective evaluations of air pollution at the county level, the effect of air pollution increases to -0.047 as is shown in column 2 . This is consistent our expectation that subjective evaluation of air pollution may result in underestimation of the effect of air pollution on fertility intentions. Using sample means of the subjective evaluation at the county level to certain extent overcome the problem with subjective evaluation of air pollution.

Estimated coefficients of other controls in columns 1 and 2 indicate that males, older people, people of minority groups, and the married have higher fertility intentions. Those who have tertiary education, who report better health conditions, and who currently work have lower fertility intentions. People who work for longer hours per week appear to want more children. Health insurance and family total income encourage people to want more children. Personal income has a negative influence on fertility intentions.

The essential estimation results are from the restricted benchmark sample reported in columns 3 and 4. Comparing estimated effects of air pollution in column 1 and column 3 , people who have lived in current places for at least five years are less affected by air pollution $(-0.024 \mathrm{Vs}-0.021)$. The same is true if we compare the estimates of air pollution in column 2 and column 4 (-0.047 Vs -0.044). The overestimation of the effects of air pollution on fertility intentions provides evidence of endogeneity that arises from people choosing living locations according to their fertility intentions.

For robustness checks, we further look at respondents who have been living in current places for at least ten years. Consequently, the sample size decreases to 4,110. After measuring air pollution using sample means of subjective evaluations at the county level, the estimated effect of air pollution on fertility intentions remains the same $(-0.044)$, being significant at $5 \%$ level. $^{2}$

\section{Conclusions}

Low fertility rates have attracted attentions in many developed countries as well as in China, as fertility rates have declined dramatically in China. Considering fertility intention is a significant predictor of fertility rate, we intend to investigate the effect of air pollution on people's fertility intentions in China.

\footnotetext{
${ }^{2}$ Estimation results are not reported in the paper, but are available upon request.
} 
Table 2. OLS estimates of the effect of air pollution on people's fertility intentions

\begin{tabular}{|c|c|c|c|c|}
\hline & Fertility intention & Fertility intention & Fertility intention & Fertility intention \\
\hline & Coeff. & Coeff. & Coeff. & Coeff. \\
\hline & $(1)$ & (2) & (3) & $(4)$ \\
\hline \multirow[t]{2}{*}{ Air pollution } & $-0.024 * *$ & $-0.047 * *$ & $-0.021 * *$ & $-0.044 * *$ \\
\hline & $(0.010)$ & $(0.020)$ & $(0.011)$ & $(0.021)$ \\
\hline \multirow[t]{2}{*}{ Gender } & $0.041 * *$ & $0.041 * *$ & 0.031 & 0.031 \\
\hline & $(0.021)$ & $(0.021)$ & $(0.022)$ & $(0.021)$ \\
\hline \multirow[t]{2}{*}{ Age } & $0.004 * *$ & $0.004 * *$ & $0.003 * *$ & $0.003^{* *}$ \\
\hline & $(0.002)$ & $(0.002)$ & $(0.002)$ & $(0.002)$ \\
\hline \multirow[t]{2}{*}{ Minority } & $0.115^{* * *}$ & $0.109 * * *$ & $0.126^{* * *}$ & $0.119 * * *$ \\
\hline & $(0.034)$ & $(0.034)$ & $(0.035)$ & $(0.036)$ \\
\hline \multirow[t]{2}{*}{ Married } & $0.133 * * *$ & $0.132 * * *$ & $0.158 * * *$ & $0.157 * * *$ \\
\hline & $(0.029)$ & $(0.029)$ & $(0.031)$ & $(0.031)$ \\
\hline \multirow[t]{2}{*}{ Tertiary education } & $-0.075 * * *$ & $-0.073 * * *$ & $-0.089 * * *$ & $-0.086 * * *$ \\
\hline & $(0.025)$ & $(0.025)$ & $(0.027)$ & $(0.027)$ \\
\hline \multirow[t]{2}{*}{ Health } & $-0.024 * *$ & $-0.024 * *$ & $-0.027 * *$ & $-0.027 * *$ \\
\hline & $(0.011)$ & $(0.011)$ & $(0.011)$ & $(0.011)$ \\
\hline \multirow[t]{2}{*}{ Work status } & $-0.087 * *$ & $-0.083 * *$ & $-0.094 * *$ & $-0.091 * *$ \\
\hline & $(0.041)$ & $(0.041)$ & $(0.044)$ & $(0.043)$ \\
\hline \multirow[t]{2}{*}{ Hours of working per week } & $0.001 * *$ & $0.001 * *$ & $0.001 * *$ & $0.001 * *$ \\
\hline & $(0.001)$ & $(0.001)$ & $(0.001)$ & $(0.001)$ \\
\hline \multirow[t]{2}{*}{ Health insurance } & $0.051 *$ & $0.049 *$ & $0.053 *$ & $0.054^{*}$ \\
\hline & $(0.031)$ & $(0.030)$ & $(0.033)$ & $(0.033)$ \\
\hline \multirow[t]{2}{*}{ Social security } & -0.032 & -0.030 & -0.036 & -0.032 \\
\hline & $(0.022)$ & $(0.022)$ & $(0.023)$ & $(0.024)$ \\
\hline \multirow[t]{2}{*}{ Personal income (1000 yuan) } & $-0.057 *$ & $-0.053^{*}$ & -0.052 & -0.049 \\
\hline & $(0.032)$ & $(0.032)$ & $(0.034)$ & $(0.034)$ \\
\hline \multirow[t]{2}{*}{ Family income (1000 yuan) } & $0.062 * * *$ & $0.062 * * *$ & $0.057 * * *$ & $0.058 * * *$ \\
\hline & $(0.016)$ & $(0.016)$ & $(0.017)$ & $(0.017)$ \\
\hline \multirow[t]{2}{*}{ Rural } & 0.033 & $0.037 *$ & 0.034 & $0.039^{*}$ \\
\hline & $(0.023)$ & $(0.022)$ & $(0.024)$ & $(0.024)$ \\
\hline Number of obs. & 4,948 & 4,948 & 4,458 & 4,458 \\
\hline
\end{tabular}

Note: Estimation results using the benchmark sample are in columns 1 and 2; results using the sample of respondents who have been living in current places for at least five years are in columns 3 and 4 . When air pollution is measured using subjective evaluations, estimates are reported in columns 1 and 3; when air pollution is measured using sample means of the subjective evaluations at the county level within each survey year, estimates are given in columns 2 and 4 . Standard errors are in parentheses.

By using data from a nationwide survey, we found a significant negative impact of air pollution on people's fertility intentions. Considering potential endogeneity may result from that people choose living locations according to their fertility intentions, we address the endogeneity issue by looking at people who have been living in current places for a long period of time. After restricting the estimation sample to people who have not changed living locations for five or ten years, the estimated effect of air pollution on fertility intention decreases but remains significant.

With rapid economic growths and the subsequent environmental pollutions, it is inevitable for the Chinese government to pay attention to taking actions to protect the environment. This can not only improve living conditions of the current generation, but also affect fertility intentions and fertility rates of the current generation, which are important for China's developments in the long run.

\section{References}

1. ARNOCKY S., DUPUIS D., STROINK M.L., 2012, Environmental concern and fertility intentions among Canadian university students, in: Population and Environment, 34(2), p. 279-292.

2. BUOLI M., GRASSI S., CALDIROLI A., CARNEVALI G. S., MUCCI F., IODICE S., CANTONE L., PERGOLI L., BOLLATI V., 2018, Is there a link between air pollution and mental disorders?, in: Environment international, 118, p. 154-168.

3. CHATTOPADHYAY P., SOM B., MUKHOPADHYAY P., 1995, Air pollution and health hazards in human subjects: Physiological and self-report indices, 
in: Journal of environmental Psychology, 15(4), p. 327-331.

4. FRUTOS V., GONZALEZ-COMADRAN M., SOLA I., JACQUEMIN B., CARRERAS R., CHECA VIZCAINO M.A., 2015, Impact of air pollution on fertility: a systematic review, in: Gynecological Endocrinology, 31(1), p. 7-13.

5. GHIMIRE D. J., MOHAI P., 2005, Environmentalism and contraceptive use: How people in less developed settings approach environmental issues, in: Population and Environment, 27(1), p. 29-61.

6. GUO W., TAN Y., YIN X., SUN A., 2019, Impact of PM2. 5 on Second Birth Intentions of China's Floating Population in a Low Fertility Context, in: International journal of environmental research and public health, 16(21), p. 4293.

7. KIM Y., MYUNG W., WON H.-H., SHIM S., JEON H.J., CHOI J., CARROLL B.J., KIM D.K., 2015, Association between air pollution and suicide in South Korea: a nationwide study, in: PloS one, 10(2).

8. MAISONET M., CORREA A., MISRA D., JAAKKOLA J.J., 2004, A review of the literature on the effects of ambient air pollution on fetal growth, in: Environmental research, 95(1), p. 106-115.

9. NIEUWENHUIJSEN M. J., BASAGAÑA X., DADVAND P., MARTINEZ D., CIRACH M., BEELEN R., JACQUEMIN B., 2014), Air pollution and human fertility rates, in: Environment international, 70, p. 914.

10. PERERA F. P., TANG D., WANG S., VISHNEVETSKY J., ZHANG B., DIAZ D., CAMANN D., RAUH V., 2012, Prenatal polycyclic aromatic hydrocarbon (PAH) exposure and child behavior at age
6-7 years, in: Environmental health perspectives, 120(6), p. 921-926.

11. RICH D. Q., LIU K., ZHANG J., THURSTON S.W., STEVENS T.P., PAN Y., KANE C., WEINBERGER W., OHMAN-STRICKLAND P., WOODRUFF T.J. ET AL., 2015, Differences in birth weight associated with the 2008 Beijing Olympics air pollution reduction: results from a natural experiment, in: Environmental health perspectives, 123(9), 880-887.

12. SCHOEN R., ASTONE N.M., KIM Y.J., NATHANSON C.A., FIELDS J.M., 1999, Do fertility intentions affect fertility behavior?, in: Journal of Marriage and the Family, p. 790-799.

13. STIEB D. M., CHEN L., ESHOUL M., JUDEK S., 2012, Ambient air pollution, birth weight and preterm birth: a systematic review and meta-analysis, in: $E n-$ vironmental research, 117, p. 100-111.

14. WONG C. M., LAI H.K., TSANG H., THACH T.Q., THOMAS G.N., LAM K.B.H., CHAN K.P., YANG L., LAU A.K., AYRES J.G. ET AL., 2015, Satellitebased estimates of long-term exposure to fine particles and association with mortality in elderly Hong Kong residents, in: Environmental health perspectives, 123(11), p. 1167-1172.

15. XUE T., ZHANG Q., 2018, Associating ambient exposure to fine particles and human fertility rates in China, in: Environmental Pollution, 235, p. 497504.

16. ZHOU M., HE G., FAN M., WANG Z., LIU Y., MA J., MA Z., LIU J., LIU Y., WANG L., ET AL., 2015, Smog episodes, fine particulate pollution and mortality in China, in: Environmental research, 136, p. 396404. 